\title{
Annual Spread Rate of Tomentosus Root Disease
}

\author{
R. S. Hunt and F. G. Peet, Research Scientists, Canadian Forest Service, Pacific Forestry Centre, 506 W. Burnside \\ Rd., Victoria, BC V8Z 1M5, Canada
}

\begin{abstract}
Hunt, R. S., and Peet, F. G. 1997. Annual spread rate of tomentosus root disease. Plant Dis. 81:1053-1056.

The spread rate of tomentosus root disease, caused by Inonotus tomentosus, was investigated by a new technique employing temporal differences in the initiation of the reduced annual radial increment between pairs of diseased trees. Pairs of infected trees (stumps) located on the periphery of disease centers were selected in each of six widely separated spruce (Picea spp.) stands in British Columbia. Distances between 12 pairs of stumps were measured, and disks were collected from each stump. Similarly, disks from four additional pairs were collected from trees in a younger stand. Uninfected control disks were collected for all sites. Tree-ring measurements were determined for all disk samples and the year in which the reduction of the annual increment attributable to I. tomentosus began was determined for infected trees. The difference between initiation years for pairs of infected trees divided into the distance between them produced an average annual spread rate of $20 \mathrm{~cm} / \mathrm{yr}$. This rate will be used in developing a model for the disease.
\end{abstract}

Tomentosus root disease, caused by Inonotus tomentosus (Fr.) Teng, causes stand openings, butt rot, and growth loss $(11,25)$ similar to other major conifer root diseases. The disease is cosmopolitan throughout boreal forests $(8,25)$ and at higher elevations in more southern latitudes in North America (6). I. tomentosus attacks most conifers (25) but is predominantly found on spruce (Picea spp.). Similar to other tree root pathogens, disease centers caused by $I$. tomentosus increase in size over time via contact between infected and healthy roots. Although spruce forests have been harvested for a long time, it is only recently that they have become intensively managed (5) and tomentosus root disease has become of concern to forest managers $(9,19)$. Consequently, little research has been conducted on this disease, unlike other major conifer root diseases, which have management models in development $(1,4,7,13,17,21,23)$.

A prerequisite and fundamental parameter for the management and modeling of any root disease is an accurate estimate of its annual rate of spread through root contact. For several root disease fungi, estimates of the spread rates are based on signs of the pathogen or on host symptoms. For example, the spread rate for Phellinus weirii (Murr.) Gilb. is based on the annual growth rate of the pathogen along roots (1). Spread rate estimates for armillaria

Corresponding author: R. S. Hunt

Accepted for publication 6 June 1997.

Publication no. D-1997-0702-01R

(C) 1997 The American Phytopathological Society root disease caused by Armillaria ostoyae (Romagn.) Herink, are based on the initiation of basal resinosus and crown symptoms $(4,15,20)$. For tomentosus root disease, it is difficult to follow the disease progress based on crown symptoms (11). In Saskatchewan, Whitney (24) inoculated roots and obtained an annual growth rate for the pathogen that increased with time since inoculation. This varied from 0.25 to $15.2 \mathrm{~cm} / \mathrm{yr}$ with a mean of $4 \mathrm{~cm} / \mathrm{yr}$.

The objective of this study was to establish an estimate of the annual spread rate for tomentosus root disease that could be used in a spread model, applicable to British Columbia. Instead of estimating a spread rate based on growth of the pathogen, it was estimated based on symptoms of the disease. A new approach to calculating the disease spread rate was attempted using the assumption that a reduction in the annual radial increment is an early above-ground symptom $(2,3,11)$ of the disease.

\section{MATERIALS AND METHODS}

The tops of stumps in nine recently harvested old-growth interior spruce (Picea glauca [Moench] Voss or P. engelmannii Engelmann) stands (100-240 years old) in the sub-boreal spruce and Engelmann spruce-subalpine fir biogeoclimatic zones (10) of the boreal forest in British Columbia were examined for honeycomb pitting, a symptom of tomentosus root disease (9). Pairs (or occasionally triplicates) of infected trees (stumps) were selected on the periphery of disease centers. The one closest to the center was designated the inoculum "source" and the one infected from it, its "mate." Triplicates were treated as two pairs with the source tree being a member of each pair A nearby stump, lacking honeycomb pitting, was selected as a control.

One younger stand, of fire origin and about 50 years of age (Pelican, Fig. 1), had roots excavated between suspect trees (those adjacent to I. tomentosus caused mortality) to determine the direction of disease spread, and 10 pairs were selected and felled. One control tree (stump) served for several pairs. The distance between all pairs of stumps (center to center) was recorded. Stump disks were removed for tree ring analysis. Some stumps were too decayed to yield unbiased radii; these were abandoned in the field. For each pair of infected trees, it was expected that the source would show annual radial increment reduction first relative to the control. The number of years between the initiation of radial increment reduction in the source and its mate was the time it took for the disease to spread from one tree to the other This number divided into the distance between them would yield an annual disease spread rate.

A Digimic (Holman Electronic Controls Ltd., Fredericton, NB, Canada) and a Measu-Chron (L. Kutschenreiter Measuring Instruments, Vienna, Austria) were used to make tree-ring measurements. The latter was used for disks that were too large for the Digimic. Two radii were selected on each disk using the following method. The length of the longest chord across the disk was measured. The length of a second chord, which was perpendicular to the first and passed through the pith, also was measured. These two lengths were added and divided by four to obtain an estimate of the radius length. Two radii of this length, which avoided decay, were located on each disk and the rings along these radii measured.

For each disk, three plots of the annual rings were produced: the two measured radii and their mean. The three plots of each source and its mate could be compared to the three plots of the control. By visual inspection, two observers independently determined and then agreed upon, how the ring patterns matched among three disks; i.e., the source, its mate, and their control. They then independently determined and then agreed upon the initiation point for annual increment reduction in both the source and its mate relative to the control. For our calculations, we attributed the initiation of these growth reductions as the first impact symptom for tomentosus root disease. 


\section{British Columbia}

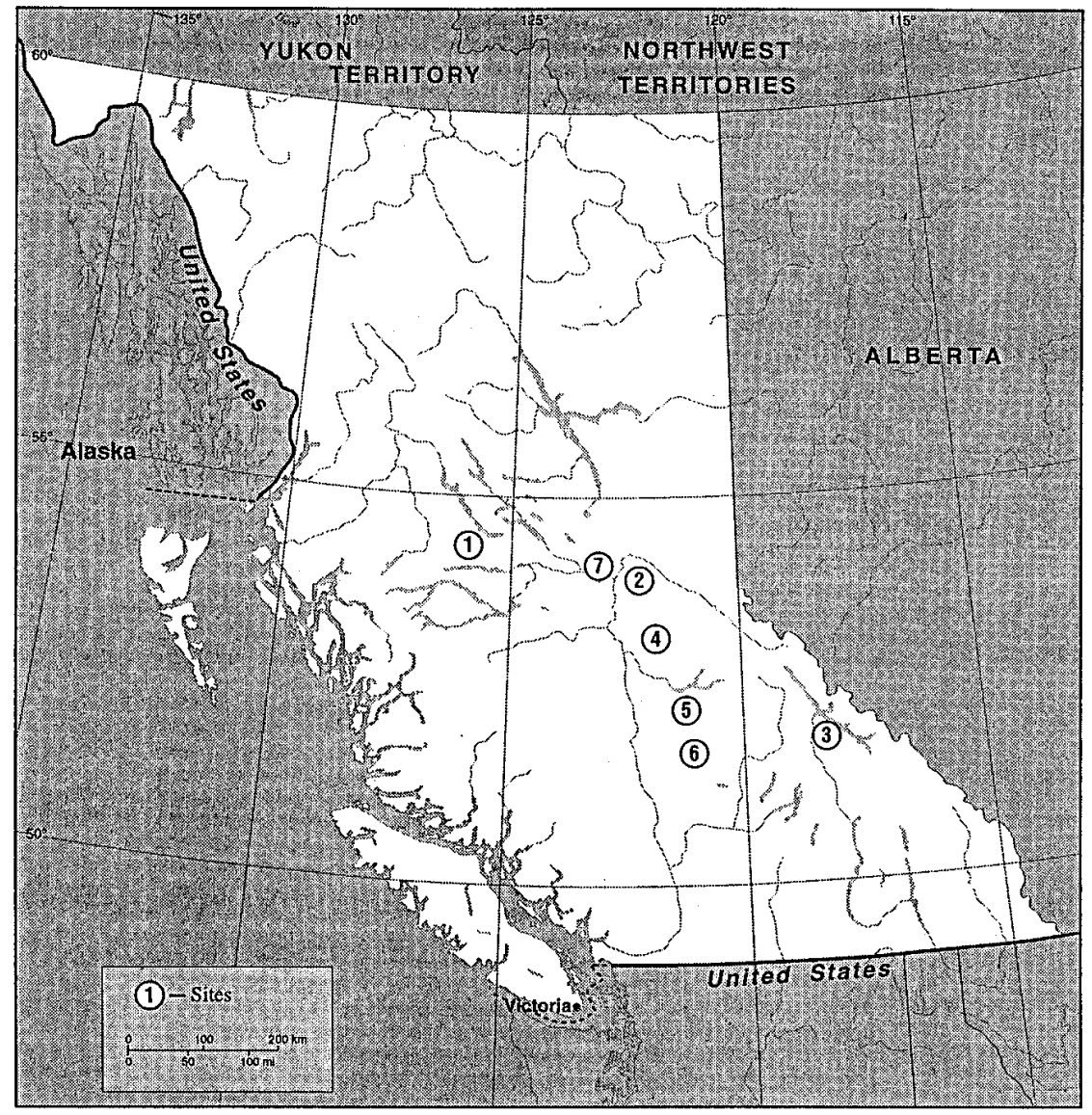

Fig. 1. Map of British Columbia showing the location of six harvested spruce stands (1-6) and one younger stand (7) from which Inonotus tomentosus infested disks were collected for increment reduction analysis. The locations are as follows (nearest town followed by site): 1) Houston (Heading Cr.), 2) Prince George (North Vama), 3) Golden (Mt. Seven), 4) Wells (2400I), 5) Likely (Black Bear), 6) Horsefly (500 Rd.), and 7) Prince George (Pelican).

\section{RESULTS}

Because disks were cut on the flaring butt of the old-growth stumps, some growth rings were cut tangentially and thus were abnormally wide. Surprisingly, this effect did not seem to influence the results except perhaps in four pairs of stumps, where the growth ring patterns were too irregular to obtain consistent observations. These samples were abandoned, reducing the number of stands from nine to six (Fig. 1) and the number of old-growth pairs from 16 to 12 . For all of the remaining infected trees (stumps) there was a consistent reduction in the growth ring patterns of the infected trees relative to both their own averages and to the growth rings of the controls.

All acceptable stump samples revealed a growth reduction in source stumps that began before the reduction in their mates (e.g., Fig. 2). Old growth samples (Fig. 2A to D) revealed a long history in their growth rings such that disturbance events or long-term trends were apparent for matching growth rings. If there were small errors in matching rings, it made little difference to the annual growth rate calculation if the stump pairs were well spaced, as the error would be spread over the total distance. The mean distance between these pairs was $4.4 \mathrm{~m}$. However, the Pelican site, with its younger and more closely spaced trees, could produce calculation errors if growth rings were not properly matched, as the error would be spread over a shorter distance. This was particularly so when one of the trees was dead. Six pairs were
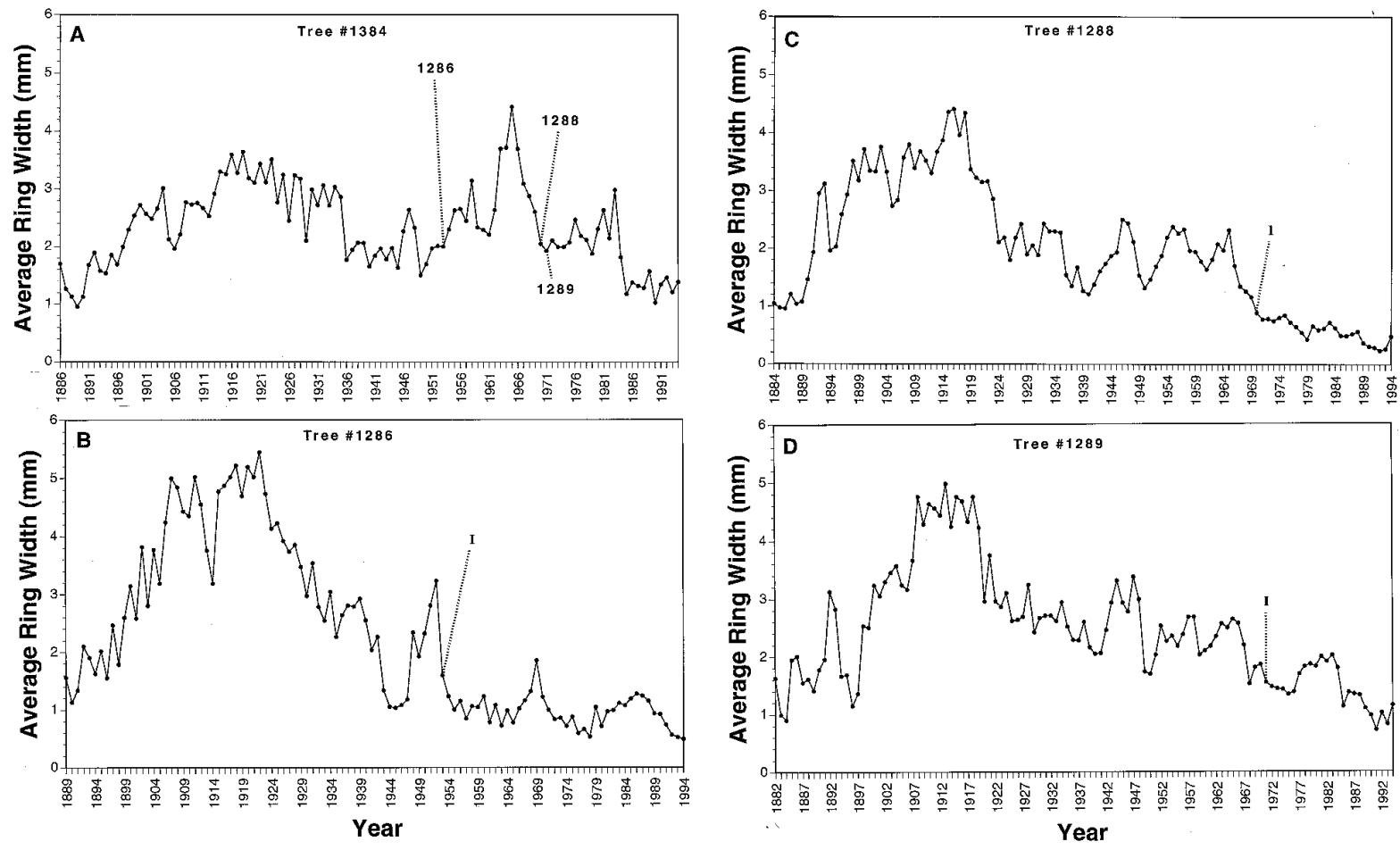

Fig. 2. Annual growth increment of old-growth forest trees infected with Inonotus tomentosus and an uninfected control collected from Golden (Mt. Seven). (A) An uninfected control (1384) with increments marked to indicate when neighboring trees $(1286,1288$, and 1289) became infected. (B) The source tree (1286) for inoculum to spread to two trees (1288 \& 1289). "I" marks the increment for the onset of disease. (C) A mate tree (1288) infected from 1286; "I" marks the increment for the initiation of disease. (D) A mate tree (\#1289) infected from 1286; "I" marks the initiation of disease. 
rejected for these reasons, and four pairs (mean distance, $1.18 \mathrm{~m}$ ) were used (e.g., Fig. 3A to F).

The annual growth rate based on each pair of disks was assigned to a growth rate class in $5 \mathrm{~cm} / \mathrm{yr}$ intervals and a bar graph produced (Fig. 4). Overall, the growth rates were normally distributed, with $62 \%$ of the samples falling into a mode of 15$25 \mathrm{~cm} / \mathrm{yr}$. The mean of the mode was 20.1 $\pm 2.3 \mathrm{~cm} / \mathrm{yr}$. and the over-all mean was $19.9 \pm 2.1$. The four samples from the younger trees all fell within the mode with a mean of $18.5 \pm 4.3 \mathrm{~cm} / \mathrm{yr}$.

\section{DISCUSSION}

Reduction in the annual radial increment of an infected tree is an early above-ground symptom of root disease $(2,3)$. Because even one root infected with tomentosus root disease may reduce the radial growth of spruce (11), it is reasonable to attribute the initiation of the maintained reduction in ring width in our disk samples to tomento- sus root disease. Although infection by $I$. tomentosus would precede this growth reduction, reduction in radial increment is the first consistent measure of disease spread within and among trees. I. tomentosus is found in boreal, or high-elevation forests, where the growing season tends to be shorter than where other conifer root pathogens are found; thus, it would be reasonable to expect the mean annual spread rate for tomentosus root disease not to exceed rates for these other pathogens. The spread rate calculated for A. ostoyae in old-growth Douglas-fir (Pseudotsuga menzieii [Mirb.] Franco) is $22 \mathrm{~cm} / \mathrm{yr}$ (20), which is less than the $1 \mathrm{~m} / \mathrm{yr}$ calculation for active centers in 25-year-old Douglasfir plantations (15) which, in turn, is less than the $2.5 \mathrm{~m} / \mathrm{yr}$ for an Armillaria $s p$. that attacks Eucalyptus sp. in warmer climates (16). The calculated growth rate for $P$. weirii, which is present in moderate temperate forests of the Pacific Northwest, is $25-34 \mathrm{~cm} / \mathrm{yr}(1,14)$, and the cal- culated growth rate for $H$. annosum in northern California is $22-39 \mathrm{~cm} / \mathrm{yr}$ (18); therefore, a mean spread rate for $I$. tomentosus of $20 \mathrm{~cm} / \mathrm{yr}$ appears reasonable. Because this rate is based on samples from seven geographic locations and the estimated rate for the other root diseases is based on fewer geographic locations, ours may be more representative than for other root diseases.

Our spread rate is considerably greater than the mean calculated pathogen growth rate $(4 \mathrm{~cm} / \mathrm{yr})$ by Whitney (24) for inoculated roots. Although one of our sites yielded this rate, it appears atypical, thus, possibly Whitney's sample site of one is also atypical. However, he reported that once inoculations were established for a few years the growth rate was faster, and from his Table IX an extrapolation for a mean of at least of $12.4 \mathrm{~cm} / \mathrm{yr}$ can be calculated. Because in our study part of the variance in the data is due to the variance in the directional growth roots take to
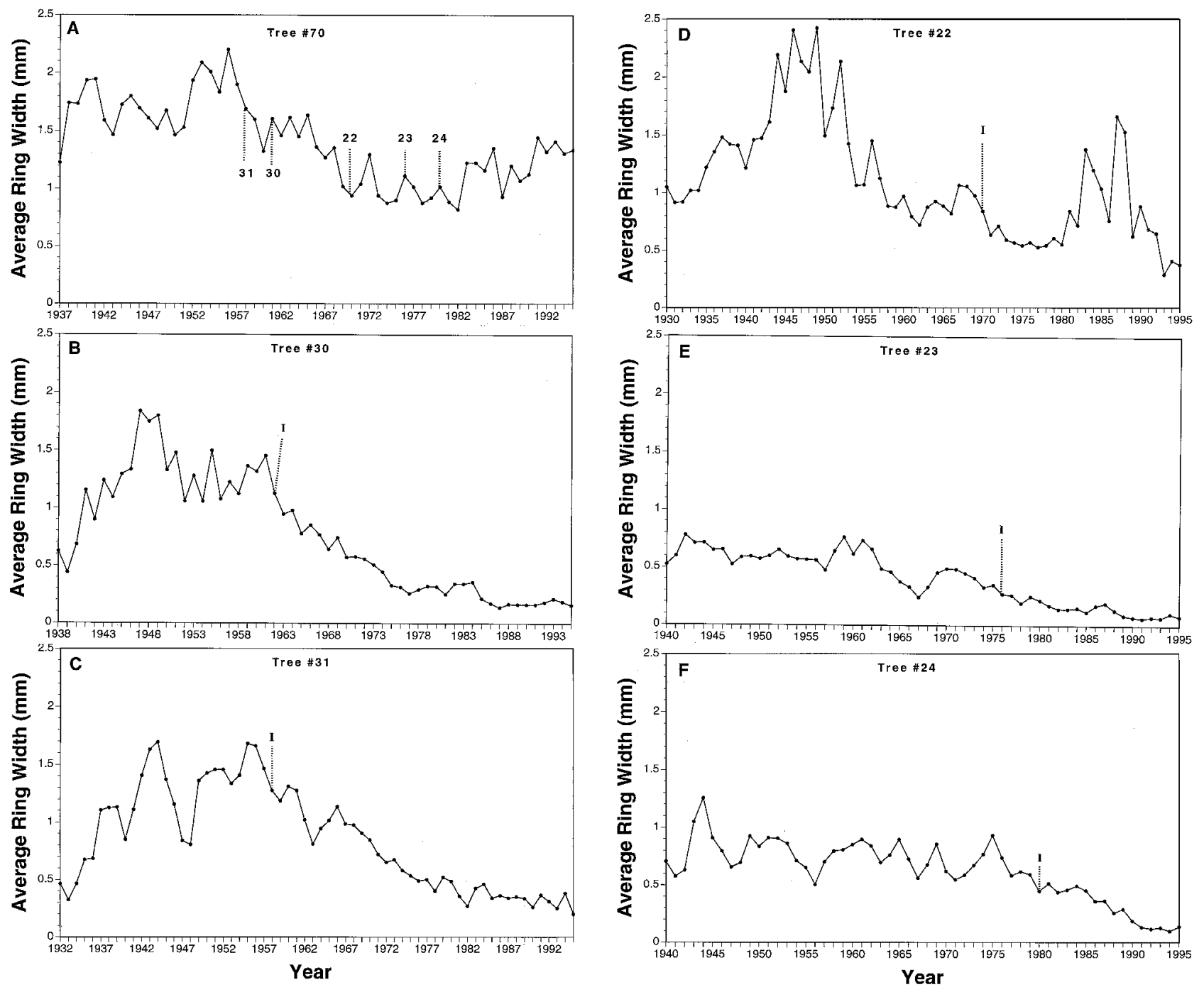

Fig. 3. Annual growth increments of young growth spruce trees infected with Inonotus tomentosus and an uninfected control collected from Prince George (Pelican). (A) An uninfected control (70) with increments marked to indicate when neighboring trees (30, 31, 22, 23, and 24) became infected. (B) A mate tree infected from 31; "I" marks the increment for the initiation of disease. (C) The source tree for infection of tree 30; "I" marks the increment for the initiation of disease. (D) The source tree (22) for trees 23 and 24; "I" marks the initiation of infection. (E) A mate tree (23) infected from 22; "I" marks the initiation of infection. (F) A mate tree (24) infected from 22; "I" marks the initiation of infection. 


\section{Rate of Spread}

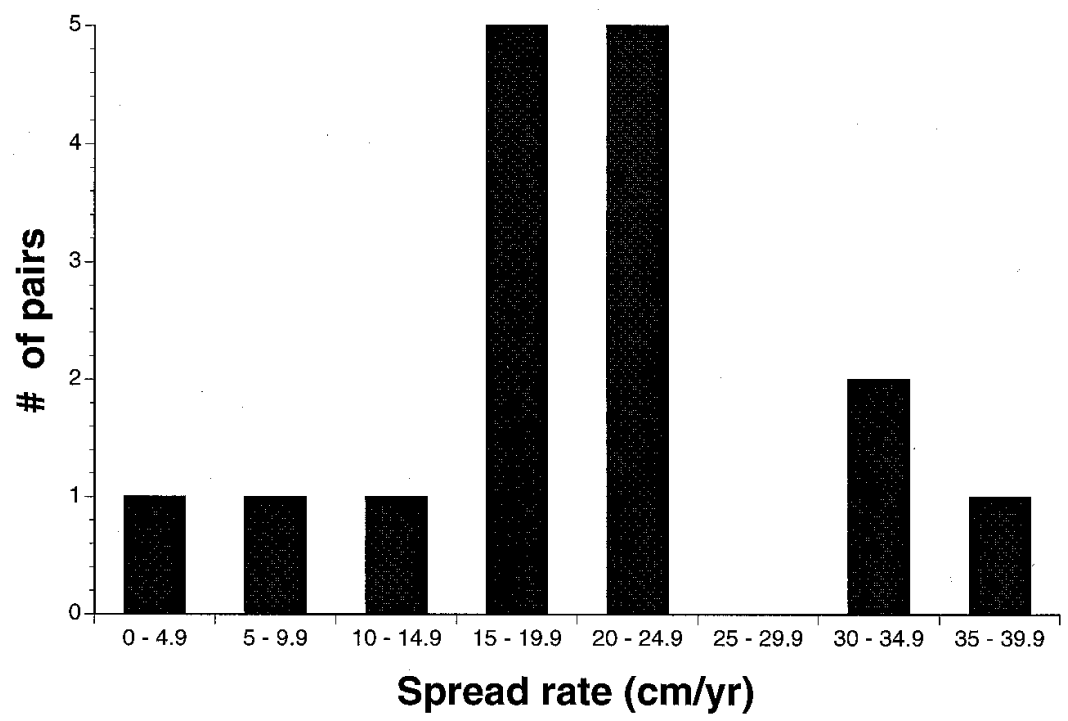

Fig. 4. Bar graph of the calculated spread rates for tomentosus root disease based on 16 stump pairs from seven collection sites in British Columbia.

make contact between hosts and transfer the pathogen from one host to the other $(12,24)$, the pathogen growth rate would need to be even faster than $20 \mathrm{~cm} / \mathrm{yr}$ to accomplish a disease spread rate of 20 $\mathrm{cm} / \mathrm{yr}$ along contact roots that are not directly opposed to one another. Conceivably, the average pathogen growth rate in British Columbia could then be more than double Whitney's $12.4 \mathrm{~cm} / \mathrm{yr}$. The colder temperatures of Saskatchewan may be more limiting to the growth of I. tomentosus than those of British Columbia, or as is known with $H$. annosum (22), site factors can affect the spread rate; at any rate, our calculation should not be transferred to other regions without further investigations in those regions.

We believe that this new technique to calculate a spread rate for root disease has been very successful for I. tomentosus and should be tried in other regions for $I$. tomentosus and other root diseases. Some possible pitfalls are growth rings cut tangentially, growth ring patterns not properly matched, and stump pairs too close together. The spread rate we have obtained will be used in developing disease models for I. tomentosus.

\section{ACKNOWLEDGMENTS}

We thank Rene Alfaro, George Brown, and Emil Wegwitz for instruction and advice on measuring annual rings with their Digimic and MeasuChron instruments and associated software. We thank the following for technical assistance: Samantha Petticrew, Jenny Clayton, Cheryl-Ann Boomhower, Mark Belton, and John Dronzek. The cooperation we received from Richard Reich, Don Carpenter and Linda Philipp of the British Columbia Ministry of Forests was invaluable.

\section{LITERATURE CITED} strategies for laminated root rot in managed Douglas-fir stands: Model development. Phytopathology 78:403-409.

2. Bloomberg, W. J., and Morrison, D. J. 1989. Relationship of growth reduction in Douglasfir to infection by Armillaria root disease in Southeastern British Columbia. Phytopathology 79:482-487.

3. Bloomberg, W. J., and Reynolds, G. 1985. Growth loss and mortality in laminated root rot infection centers in second-growth Douglas-fir on Vancouver Island. For. Sci. 31:497508.

4. Bruhn, J. N., Mihail, J. D., and Meyer, T. R. 1996. Using spatial and temporal patterns of Armillaria root disease to formulate management recommendations for Ontario's black spruce (Picea mariana) seed orchards. Can. J. For. Res. 26:298-305.

5. Coates, D. K., Haeussler, S., Lindeburgh, S., Pojar, R., and Stock, A. J. 1994. Ecology and Silviculture of Interior Spruce in British Columbia. Can-BC, FRDA II, 182 pp.

6. Farr, D. F., Bills, G. F., Chamuris, G. P., and Rossman A. Y. 1989. Fungi on Plants and Plant Products in the United States. APS Press, St. Paul, MN.

7. Frankel, S. J., Eav, B. B., Kliejunas, J. T., and Shaw, C. G., III. 1994. Modelling the dynamics and impact of annosus root disease in western North America. Pages 762-770 in: Proc. Int. Congr. Root Butt Rots, 8th. M. Johansson and J. Stenlid, eds.

8. Gilbertson, R. L., and Ryvarden, L. 1986. North American Polypores. Fungiflora 1:403.

9. Hunt, R. S., and Unger, L. 1994. Tomentosus root disease. Can. For. Serv. Pac. For. Cent. For. Pest Leafl. 77.

10. Klinka, K., Feller, M. C., Green, R. N., Meidinger, D. V., Pojar, J., and Worral, J. 1990. Ecological principles: Applications. Pages 55-72 in: Regenerating British Columbia's Forests. D. Lavender, ed. University of BC Press, Vancouver, BC.
1. Bloomberg, W. J. 1988. Modeling control
11. Lewis, K. J. 1994. The effect of Inonotus tomentosus on the growth and crown vigour of spruce (Picea glauca $\times$ engelmannii). Pages 194-207 in: Proc. Int. Congr. Root Butt Rots, 8th. M. Johansson and J. Stenlid, eds.

12. Lewis, K. J., and Hansen, E. M. 1991. Vegetative compatibility groups and protein electrophoresis indicate a role for basidiospores in the spread of Inonotus tomentosus in spruce forests of British Columbia. Can. J. Bot. 69:1756-1763.

13. McNamee, P., Sutherland, G., Shaw, C. G., III, Stage, A., Byler, J., Crookston, N., Eav, B., Goheen, D., Harvey, A., Marsden, M. Martin, N., McDonald, G., Morrison, D., Theis, W., and Webb, T. 1989. Description of a muti-species root disease model developed for silvicultural planning and management in coniferous forests of western North America. Pages 320-335 in: Proc. Int. Congr. Root Butt Rots, 7th. D. J. Morrison, ed.

14. Nelson, E. E., and Hartman, T. 1975. Estimating spread of Poria weirii in a high elevation, mixed conifer stand. J. For. 73:141-142.

15. Peet, F. G., Morrison, D. G., and Pellow, K. W. 1996. Rate of spread of Armillaria ostoyae in two Douglas-fir plantations in the southern interior of British Columbia. Can. J. For. Res. 26:148-151.

16. Podger, F. D., Kile, G. A., Watling, R., and Fryer, J. 1978. Spread and effect of Armillaria luteobubalina sp. nov. in an Australian Eucalyptus regnans plantation. Trans. Br. Mycol. Soc. 71:77-87.

17. Pratt, J. E., Redfern, D. B., and Burnand, A. C. 1994. Modelling the spread of Heterobasidion annosum in Sitka spruce plantations in Britain. Pages 320-335 in: Proc. Int. Congr. Root Butt Rots, 7th. D. J. Morrison, ed.

18. Slaughter, G. W., and Parmeter, J. R., Jr. 1995. Enlargement of tree-mortality centers surrounding pine stumps infected by Heterobasidion annosum in northeastern California. Can. J. For. Res. 25:244-252.

19. Tkacz, B. M., and Baker, F. A. 1991. Survival of Inonotus tomentosus in spruce stumps after logging. Plant Dis. 75:788-790.

20. van der Kamp, B. J. 1993. Rate of spread of Armillaria ostoyae in the central interior of British Columbia. Can. J. For. Res. 23:12391241.

21. Vollbrecht, G. 1994. Modelling incidence of root rot in Picea abies plantations in southern Sweden. Pages 771-778 in: Proc. Int. Congr. Root Butt Rots, 8th. M. Johansson and J. Stenlid, eds.

22. Vollbrecht, G., and Agestam, E. 1994. Modelling incidence of root rot in Picea abies plantations in southern Sweden. In: Effects of Silvicultural Practices on the Incidence of Root and Butt Rot in Norway spruce with Special Emphasis on Heterobasidion annosum. Swedish University of Agric. Sci. Southern Swedish For. Res. Centre, Alnarp.

23. Vollbrecht, G., and Jorgensen, B. B. 1995 Modelling the incidence of butt rot in plantations of in Denmark. Can. J. For. Res. 25:1887-1896.

24. Whitney, R. D. 1962. Studies in forest pathology XXIV. Polyporus tomentosus Fr. as a major factor in stand-opening disease of white spruce. Can. J. Bot. 40:1631-1658.

25. Whitney, R. D. 1977. Polyporus tomentosus root rot of conifers. Can. For. Serv. Great Lakes For. Cent. For. Tech. Rep. 18. 